\title{
Soil Fertility Analysis of Smallholder Farms in Bugaje and Kusa Villages of Jibia Local Government Area, Nigeria
}

\author{
Ibrahim, Y. El-Ladan ${ }^{1}$ and Nuraddeen A. Maiwada \\ (Department of Geography, Umaru Musa 'Yar-adua University, Katsina - Nigeria.)
}

\begin{abstract}
Fertility indices of physical and chemical properties of the soils of Bugaje and Kusa Villages of Jibia Local Government Area were investigated. Four samples (two from cultivated land and two from un-cultivated land) were collected using stratified random sampling. The samples were analyzed for Particle Size Distribution, pH, Organic Carbon, Total Nitrogen, Available Phosphorus and CEC. Findings revealed that the fertility indices investigated were very low and the percentage sand values of the cultivated were higher compared to that of the un-cultivated land, probably attributable to the effects of soil management over the years. Hence, soil fertility maintenance strategies should be adopted through appropriate practices and farming activities should be closely monitored in order to counteract possible future adverse changes.
\end{abstract}

Keywords: Jibia local government, Smallholder farms, Soil fertility

\section{Introduction}

Agricultural lands are under increased pressure consequence of extensive usage as well as nutrient looses due to natural and man-made factors. In Nigeria, Soil fertility maintenance has been widely recognized as a major problem that greatly affects agricultural development (Kolawale, 2002) ${ }^{[1]}$. Soil fertility is being maintained through various conservation methods. The nature of the conservation methods varies from place to place, depending on several factors like precipitation, topography, vegetation, soil type etc. Furthermore, as soils vary widely from place to place, many factors determine their physical and chemical compositions, structure etc. according to location. The different kinds of rocks, minerals, and other geologic materials from which the soil originally formed play a role. The kinds of plants or other vegetation that grow on the soil are also important, (Asadu et al, 1997) ${ }^{[2]}$. This study was initiated to investigate the influence of some land-use practices on the fertility status of some soils. The need for such information constitutes the problem of interest over which this study seeks to advance an understanding, using Bugaje and Kusa Villages of Jibia Local Government Area as a case study. The aim of this work, therefore, is to assess the soil fertility status of smallholder farms in Bugaje and Kusa villages of Jibia Local Government Area, Katsina State. The objective is to determine the fertility status of the soils in terms of contents of basic essential elements including organic carbon, total nitrogen, available phosphorus, $\mathrm{pH}$, cations exchange capacity and particle size distribution as well as propose appropriate management measures aimed at improving the condition of the soils for sustainable utilization, where possible.

\subsection{Geographical Description of the Study Area}

\section{Materials and Methods}

Jibia is a town and Local Government headquarters in Katsina State. It is located on the central plain of Hausa land of Northern Nigeria and lies between Latitude $13^{\circ} 0^{\prime} 30^{\prime} \mathrm{N}$ and Longitude $7^{0} 35^{\prime} 13^{\prime} \mathrm{E}$. It is situated on the extreme part of Northern Nigeria, bordering Niger Republic to the North, Katsina and Kaita Local Government Areas to the North East, and to the South by Batsari and Batagarawa Local Government Areas. 


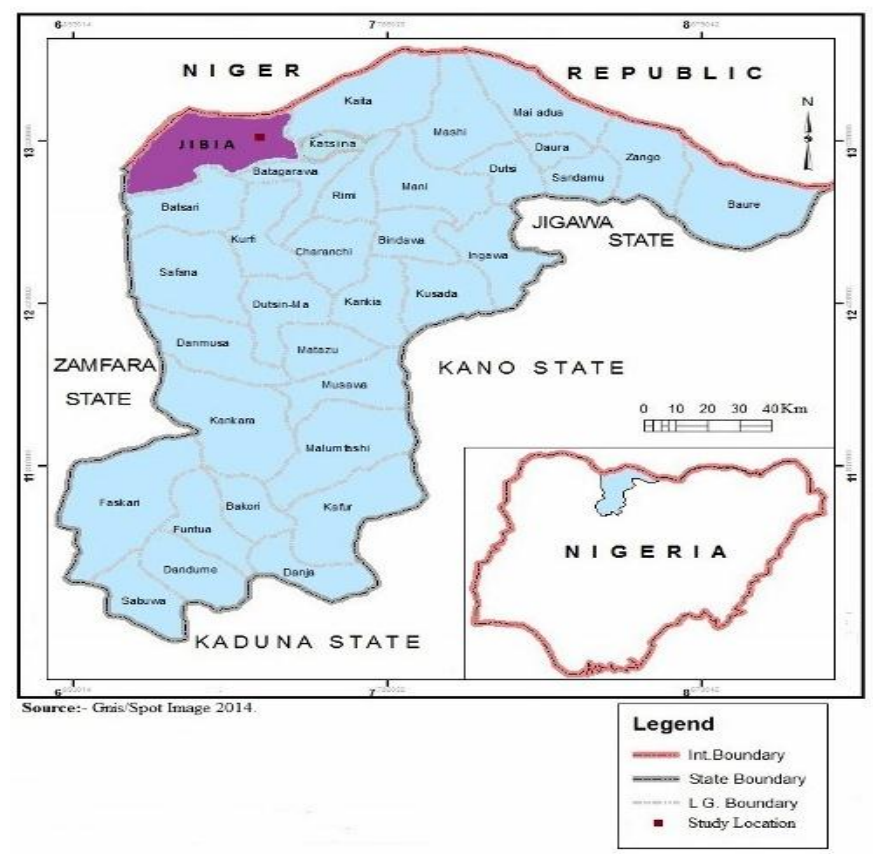

Fig. 1: Map of Nigeria showing the location of the study area.
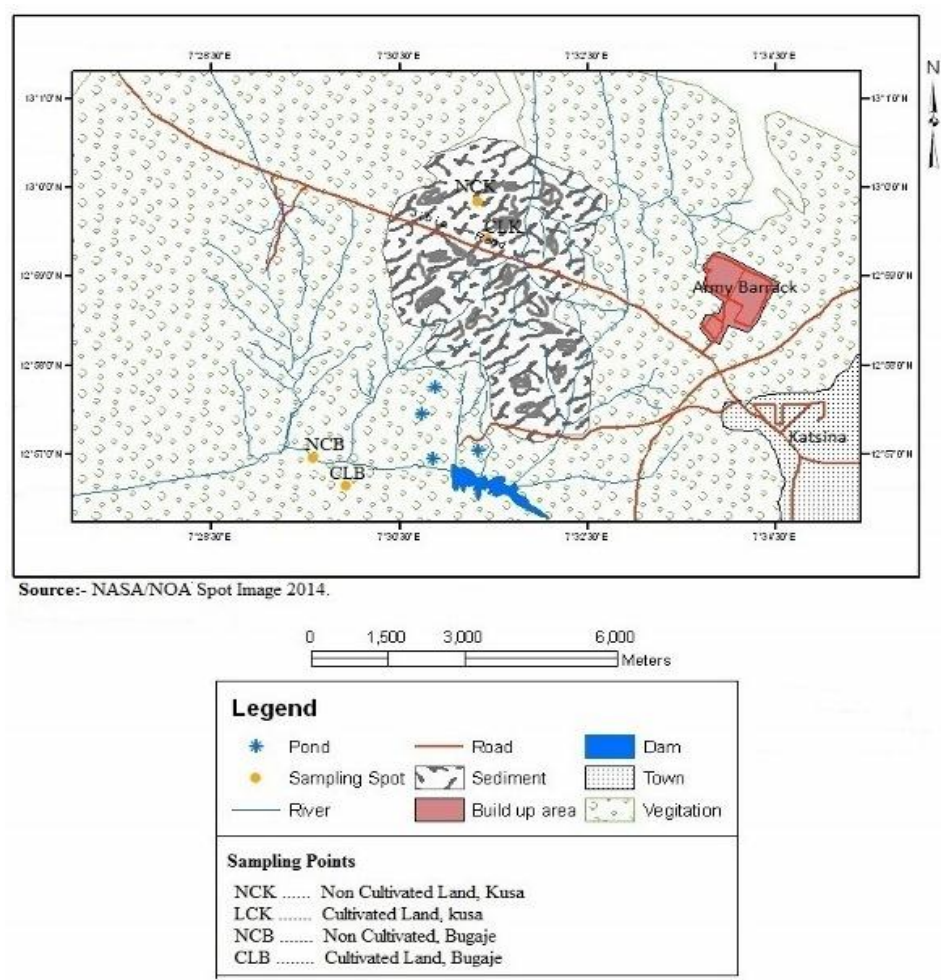

\subsection{Samples collection}

Fig. 2: Soil sampling points.

Soil samples were obtained from Bugaje and Kusa Districts. In each of these locations, cultivated and non-cultivated areas were randomly selected, thus, a total of four samples were collected. The Samples were collected at a depth of 0-30 cm between late April and the first week of June, 2013 using steel auger.

\subsection{Samples Analysis}

The samples were air-dried, passed through a $2 \mathrm{~mm}$ sieve mesh and analyzed for $\mathrm{pH}$ in 1:2 soil-water suspensions and $0.01 \mathrm{~m} \mathrm{CaCl}$; Organic carbon, following Walkley-Black (1934) ${ }^{[3]}$ method; Total Nitrogen, using the micro-Kjeldahl procedure; Exchangeable cations via $\mathrm{NH}_{4} \mathrm{OAc}$ digestion; Available phosphorus by Bray-1 (1945) ${ }^{[4]}$ method and particle size distribution using hydrometer method (Bouyoucos, 1936) ${ }^{[5]}$. 
III. Results and Discussions

Table1: Results of soil physico-chemical analysis for the cultivated sites

\begin{tabular}{|c|c|c|c|c|c|c|c|c|}
\hline SAMPLE ID & pH & OC (\%) & $\begin{array}{c}\text { CEC } \\
\text { (me/100g) }\end{array}$ & $\begin{array}{c}\text { Total N } \\
\text { (\%) }\end{array}$ & $\begin{array}{c}\text { AVP } \\
\text { (ppm) }\end{array}$ & & \multicolumn{4}{|c|}{ PSD } \\
\cline { 5 - 9 } & & & & & & Sand (\%) & Silt (\%) & Clay (\%) \\
\hline CLK & 5.4 & 7.4 & 2.7 & 1.1 & 0.01 & 92.26 & 9.19 & 1.72 \\
\hline CLB & 5.6 & 7.3 & 9.3 & 1.7 & 0.16 & 90.26 & 20.26 & 0.50 \\
\hline
\end{tabular}

CLK - Cultivated Land, Kusa

CLB - Cultivated Land, Bugaje

Table 2: Results of soil physico-chemical analysis for the non-cultivated sites

\begin{tabular}{|c|c|c|c|c|c|c|c|c|}
\hline \multirow[t]{2}{*}{ SAMPLE ID } & \multirow[t]{2}{*}{ pH } & \multirow[t]{2}{*}{ OC (\%) } & \multirow[t]{2}{*}{ CEC (me/100g) } & \multirow[t]{2}{*}{ Total N (\%) } & \multirow{2}{*}{$\begin{array}{c}\text { AVP } \\
\text { (ppm) }\end{array}$} & \multicolumn{3}{|c|}{ PSD } \\
\hline & & & & & & Sand (\%) & Silt (\%) & Clay (\%) \\
\hline NCK & 5.6 & 7.3 & 2.4 & 1.9 & 0.09 & 90.26 & 9.41 & 1.0 \\
\hline NCB & 5.0 & 7.6 & 3.9 & 2.1 & 0.08 & 88.26 & 30.26 & 0.40 \\
\hline
\end{tabular}

NCK - Non-cultivated Land, Kusa

NCB - Non-cultivated Land, Bugaje

$3.1 \mathrm{pH}$

The results indicated that the cultivated land in Kusa has a $\mathrm{pH}$ of 5.4, which is slightly lower than that of the non cultivated land ( $\mathrm{pH}$ of 5.6). The cultivated land in Bugaje has $\mathrm{pH}$ of 5.6, higher than that of the noncultivated land by 0.6 . The values for the cultivated lands may be considered as normal for the soils of the area. Landon, (1991) ${ }^{[6]}$ explained the effects of low and high $\mathrm{pH}$ on plant nutrients availability. pH of less than 5.5 result in phosphates forming complexes of $\mathrm{Fe}, \mathrm{Mn}$ and $\mathrm{Al}$ compounds which are not readily available to plants. There is also a decrease in bacterial activities when $\mathrm{pH}$ is high, retarding nitrification of organic matter.

\subsection{Organic Carbon}

The results shows that the cultivated land of Kusa has organic carbon content of $7.4 \%$, showing an increase of $0.1 \%$ to that of the non-cultivated land which has a value of $7.3 \%$ while cultivated land in Bugaje has $7.3 \%$, a lower value than that of the non-cultivated land $(7.6 \%)$. Kodiya, (1988) ${ }^{[7]}$ stated that a soil with organic carbon content of $0.00-0.75$ is rated as extremely low, $0.75-1.25$ is rated as medium low, $1.25-2.00$ as very high, $4.00-7.5$ as extremely high. Thus, soils in the study area fall within the range of $4.00-7.50$ values, which indicate extremely high organic carbon content. Agboda and Corey, (1973) ${ }^{[8]}$ states that soil organic matter in agro-ecosystem is regarded as an important source of soil nutrients and determining factor in the availability of majority of nutrients to crops.

\subsection{Cations Exchange Capacity}

The Cations Exchange is an overall assessment of the potential fertility of a soil and the values depend critically on soil $\mathrm{pH}$ (Kodiya, 1988). The results obtained indicated that the soil of cultivated land in Kusa has a CEC of $2.7 \mathrm{me} / 100 \mathrm{~g}$, portraying a difference of $-0.3 \mathrm{me} / 100 \mathrm{~g}$ to that of non-cultivated land which had $2.4 \mathrm{me} / 100 \mathrm{~g}$, while the cultivated land of Bugaje has a CEC of $9.3 \mathrm{me} / 100 \mathrm{~g}$, with a difference of $5.4 \mathrm{me} / 100 \mathrm{~g}$ to that of non-cultivated land which had a value of $3.9 \mathrm{me} / 100 \mathrm{~g}$. Ludwig, et al (2001) ${ }^{[9]}$ noted that soils with low CEC might have been subjected to leaching of nutrients like nitrogen, potassium and magnesium. Therefore, such soils have lower yield potentials than those with higher CECs (Asadu et al, 1997). According to Asadu et al, (1997) low values of CEC may be attributed to low clay and humus contents as well as low pH values. They indicate a degree of soil infertility. Therefore, for the purpose of cultivation the soils in the study area need appropriate management practices through the addition of organic, or if that is not possible, chemical fertilizers.

\subsection{Total Nitrogen}

Soil nitrogen is very dynamic and is constantly shifting back and forth between organic and inorganic forms. Nitrogen influences the decomposition of organic matter in the soil which ultimately leads to its fertility (Essiet, 1990) ${ }^{[10]}$. Compared to that of non-cultivated land with total nitrogen of $2.1 \%$, with difference of $0.4 \%$, the cultivated soil in Bugaje has total nitrogen of $1.7 \%$. In Kusa, the values were $1.1 \%$ and $2.1 \%$ for the cultivated and non-cultivated lands respectively. According to Kodiya, (1988) soil total nitrogen values below 0.05 is rated as very low, $0.05-0.10$ is low, $0.10-0.15$ as medium low, $0.20-0.25$ as medium high, $0.20-$ 0.25 is high, above 0.3 as very high. The soils in the study area fall within the range of above 0.30 and may therefore, be rated as very high in terms of total nitrogen contents. 


\subsection{Available Phosphorus}

The results of soil analysis in Tables 1 and 2 shows that the cultivated land in Kusa had lower available phosphorus $(0.01 \mathrm{ppm})$ than the non-cultivated land $(0.09 \mathrm{ppm})$, while the cultivated land of Bugaje had higher values of available phosphorus $(0.16 \mathrm{ppm})$ than the non-cultivated land which had $0.08 \mathrm{ppm}$. Karikari and Yayock, (1987) ${ }^{[11]}$ reported that, soils of West African Savannah have an average phosphorus values of $4.70 \mathrm{ppm}$, which are generally considered as very low. National Fertilizer Center, $(1988)^{[12]}$ report values of $5.00 \mathrm{ppm}-4.00 \mathrm{ppm}$ for North - West Zone Savannah soils. In comparison, the values obtained in this study are lower than what has been reported for upland soils of the Savannah zone. The implications of these findings are that phosphorus would not be available for plant absorption since the values do not reach 10.00 as opined by Kodiya, (1988) that if a soil has a range of available phosphorus of $121.00-140.00$ it is considered very high, $61.00-80.00$ is considered medium high, $30.00-60.00$ is medium, $21.00-30.00$ medium low, $11.00-20.00$ low and $0.00-10.00$ is very low. Incessant bush burning might be responsible for these low values.

\subsection{Particle Size Distribution}

According to Essiet, $(2001){ }^{[13]}$ for any soil, its fertility would be determined by two compounds, clay and organic matter. In tropical soils, however, the clay fraction has been so intensively weathered that its role in enhancing soil fertility is minimal and often very negligible. The result in this study shows that the soils studied were predominantly sandy $(88.26 \%-92.26 \%$ sand). The percentages of silt and clay were comparatively low (30.26\% and $1.72 \%$ as upper limits respectively). This may be the resultant problem of the prolonged movement of the tropical continental air mass in the area, deposition from the neighboring fringes of the Sahara desert, or the consequence of deforestation which is very apparent in the area.

\subsection{Conclusion}

\section{Conclusion}

This study was designed with the aim of investigating the influence of some land-use practices on the fertility status of some soils. A methodology was employed that involved stratified random sampling in which the farm lands were stratified into units based on physiographic and management systems. Soil samples collected were analyzed in the laboratory for some physical and chemical properties. The results obtained indicate differences in the soil properties, confirming the influence of land-use practices on the fertility statuses of the soils studied.

\subsection{Recommendations}

Appropriate soil conservation measures should be employed by farmers in the study area, including all the relevant measures of soil conservation such as crop rotation, mixed cropping, inter-plating, zero cultivation etc. These measures would check the problem of soil fertility depletion which is shown to be the most potential cause of land degradation. In order to improve and maintain the fertility status of the soils in the study area, periodic soil analysis should be carried out so as to assist in proportionate applications of manures.

\section{References}

[1] Kolawale, O. D. Facts associated with utilization of indigenous knowledge system of soil fertility conservation by farmers in Ekiti state, Nigeria. PhD thesis, Department of Agricultural Extension and Rural Sociology, Obafemi Awolowo University, Ile-Ife, Nigeria, 2002.

[2] Asadu, C. L. A., J. Diels, and B.Vanlauwe, A comparison of the contributions of clay, silt, and organic-matter to the effective CEC of soils of sub-saharan Africa, Soil Sci. 1997, 162: 785-794.

[3] Walkley, A. and I. A. Black, Determination of organic carbon in soils, Soil Sci. 1934, 37: 29 - 38

[4] Bray, R. H. and L. T. Kurtz, Determination of available forms of phosphorus in soils. Soil Sci. 1945, $59: 39-45$.

[5] Bouyoucos, G. J. Directions for making mechanical analyses by the hydrometer method. Soil Sci. 1936, $42: 225-229$.

[6] Landon, J.R., Booker tropical soil manual: A handbook for soil survey and agricultural land evaluation in the tropics and subtropics. (Longman Scientific and Technical. Essex, New York 1991).

[7] Kodiya, H. M.. Effects of irrigation on some soil characteristics in the south Chad irrigation project. M.Sc Thesis, Department of Geography, Bayero University, Kano, 1998.

[8] Agbola, A. A. and R. B. Corey, Relation between soil pH, organic matter, average P, exchangeable $\mathrm{K}, \mathrm{Ca}$, Mg and nine elements in maize tissue. Soil Sci. 1973, 115: $367-375$.

[9] Ludwig, D., M. Mangel, and B. Haddad, Ecology, conservation, and public policy. Annual Review of Ecology and Systematic. 2001, 32, 481-517.

[10] Essiet, E. U. A comparison of soil degradation under smallholder farming and large-scale irrigated land in Kano State, Northern Nigeria. Land Degradation and Rehabilitation. 1990, 2, $209-214$.

[11] Kari-Kari, S. K. and J. Y. Yayock, Organic fertilizer sources in Nigeria, Proc. of the National Fertilizer Seminar held at Port Harcourt, Nigeria, 1987, $70-82$.

[12] National Fertilizer Centre, 1987/88, Annual report. (Obasola Commercial Enterprises, Ibadan 1988).

[13] Essiet, E. U. Agricultural sustainability under smallholder farming in Kano, Northern Nigeria. Journal of Arid Environment. 2001, $48,1-7$. 